\section{Battle joined on animal lib}

\section{Los Angeles}

Californian investigators whose research animals have been stolen, whose laboratories have been vandalized, whose work has been disrupted and whose very lives have been threatened by "animal liberation" activists, are fighting back.

Earlier this month, several of them testified before a Californian Assembly committee on public safety which subsequently approved a bill that would stiffen the penalties for stealing research animals. An animal "liberator" currently faces misdemeanour charges, punishable by up to three months in county gaol and a fine, provided the animal is worth less than $\$ 400$. The bill, if passed into law, would allow a judge to punish such a thief as a felon, with a 16-month to 3-year state prison term plus fines, no matter how inexpensive the animals.

"We are addressing the basic problem, which is interruption of research", says assemblyman William J. Filante, a northern Californian Republican who introduced the legislation. As the state legislature's only physician, Dr Filante said he feels an obligation to stiffen the penalties: "We are talking about vandalism, terrorism, destruction and theft".

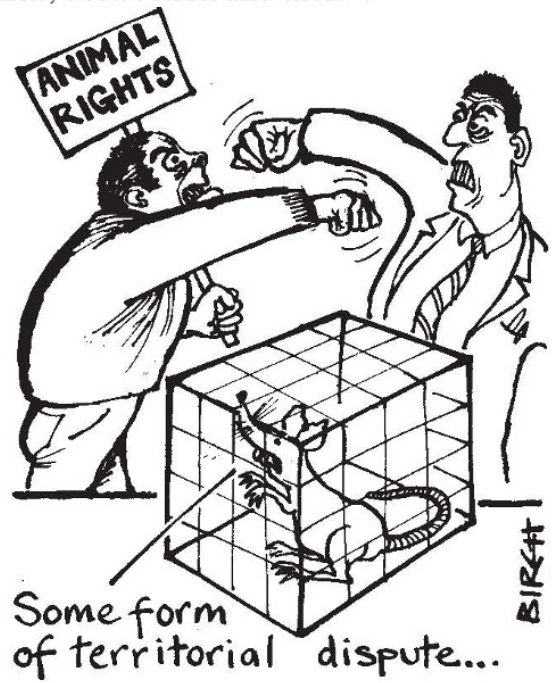

Californian research facilities are threatened by ever bigger and bolder attacks, according to Sandra Bressler, executive director of the California Biomedical Research Foundation. The organization was set up last year, she says, to educate the public about how and why animals are used in biomedical research. California's leading universities, research clinics and other health organizations have joined the "fight back".

The problems began in 1982 when two monkeys used in brain research at the University of California (UC) at San Francisco were videotaped by interlopers. The tape was shown in Canada to raise money for animal rights groups. In 1983 , two cats were stolen from a UC Berkeley

Plant biotechnology campus psychology laboratory and twelve dogs used in cardiovascular research were taken from the Harbor-UCLA Medical Center in Los Angeles. The dogs, each valued at $\$ 5,000$, wore pacemakers; research was delayed one year and the total loss was estimated to be $£ 100,000$.

In 1984, there were incidents of animal theft and vandalism at UC Sacramento and at the City of Hope Medical Center in Duarte. A $\$ 400,000$ cancer study at Duarte was set back three years. There were also cases of threats and paintspraying at UC Davis and San Diego.

In January this year, 11 rabbits were taken from a Napa county animal shelter and the chairman of the department of surgery at UC San Diego received a death threat. Two months later, the home and car of the Los Angeles county animal control director were vandalized. And in April 467 animals were stolen from labor- atories at UC Riverside, ruining eleven projects and causing damage assessed at $\$ 683,000$

UC San Diego biology professor Mark Chappell lost 305 deer mice that he had painstakingly bred for five years to study variations in haemoglobin. Also in April, a student spirited away a cat being used to demonstrate premature infant resuscitation techniques at Stanford University.

None of the thieves, most of whom claim to belong to the Animal Liberation Front, has been caught, although there is one suspect from the Riverside incident and one person has been identified as passing on rabbits stolen from the City of Hope Medical Center.

The California legislature is under considerable pressure both from the biomedical community, which is powerful in California, and the animal rights activists, who are extremely vocal. Most legislators would like the problem to "go away", said an aide to Dr Filante. "But we expect it to stay a major issue for a long time. It ${ }^{\dagger} l l$ be a big fight."

Sandra Blakeslee

\title{
Young men go East to Georgia
}

Washington

THE University of Georgia, hoping to establish itself as a world-class centre for plant biotechnology, has acquired as a job lot a 20-strong research group from the University of Colorado. It has also committed $\$ 5$ million over the next five years to establish 25 new faculty positions in molecular biology. The state of Georgia has demonstrated its support with a promise of $\$ 32$ million for a new biotechnology building on the university's campus at Athens. The newly-hired research group is that of Peter Albersheim, who will be director of the new Center for Complex Carbohydrate Research. Albersheim let it be known last fall that he was planning to leave Colorado: Georgia was able to persuade him to Athens with an offer of almost 10,000 square feet of unused laboratory space in the Richard B. Russell Research Building, a facility of the US Department of Agriculture (USDA).

The new carbohydrate research group will work in collaboration with USDA scientists, and is expected to expand to a total staff of up to 40 . Another reason Albersheim chose Georgia is the university's commitment to expand its biological research activities, which (including contract research) amounted to $\$ 75$ million last year. About half of the promised 25 new faculty positions are likely to be in Albersheim's group, which brings with it from Colorado $\$ 1$ million in research grants. Albersheim sees an impending golden age for the study of carbohydrates, which have tended to receive far less attention than other biopolymers. Now, he points out, it is becoming clear that carbohydrates, both individually and () 1985 Nature Publishing Group combined with proteins, play an important role in controlling metabolism and may dominate immunological reactions. Genetic engineering companies that have hithertoconcentratedattentionon proteins will in future have to pay more attention to carbohydrates, Albersheim believes. The University of Georgia has long nursed aspirations to be renowned for something. When president Fred Davison started looking at the available options, plant biotechnology seemed a likely choice.

It is planned that the faculty expansion over the next few years will be complemented by an international Information Center for Plant and Animal Biotechnology. This scheme, still rather vague, is intended to provide information to plant and animal breeders who may be aware of the potential of the new biotechnology but who do not know where to find researchers working in relevant areas.

According to Leon Dure, a professor of biochemistry at Georgia, there is a "distinct gap" in the knowledge of plant breeders about how recent developments might help their work. Dure expects that the member institutes of the World Bank's Consultative Group for International Agricultural Research, which includes crop and animal breeding centres all over the world, will be among the users of the new centre. In its initial phase the centre will concentrate on putting researchers and potential clients into contact with one another; later, it is hoped that more technical information, including gene and protein sequences and possibly complete scientific papers, will be included.

Tim Beardsley 